\title{
KEBIJAKAN PENGAMPUNAN PAJAK (TAX AMNESTY) BERDASARKAN KEADILAN YANG MENDUKUNG IKLIM INVESTASI INDONESIA*.
}

\author{
Nabitatus Sa'adah \\ Fakultas Hukum Universitas Diponegoro Semarang \\ Prof.Soedarto,SH No.1 Tembalang Semarang, Jawa Tengah \\ N4b1t4tuz@yahoo.com
}

\begin{abstract}
Tax amnesty policy in the beginning generates controversy due to its capacity to provide a contribution to the increase in state revenue and investment was in doubt. Tax amnesty policy is considered unfair to law-abiding the taxpayer. Several subjects need to be analyzed on how tax amnesty policy is related with fairness? And how tax amnesty shall be modeled to provide fairness also able to increase investment nature in Indonesia? This research is adopting socio-legal research approach model. Tax amnesty policy shall be seen from the principle of benefit, which is an increase of state revenue. The effort to provide fairness, tax payer who receives an amnesty, has to pay penalty, and receive law enforcement. The increase of investment in Indonesia needs to be supported with ease of bureaucracy of permits, conducive politics, and assurance of secrecy and legal certainty.
\end{abstract}

Keywords: Tax Amnesty, Tax

\begin{abstract}
Abstrak
Kebijakan tax amnesty pada awalnya menjadi kontroversi karena diragukan kemampuannya dalam memberi peningkatan kontribusi terhadap penerimaan negara serta meningkatkan investasi di Indonesia. Kebijakan tax amnesty dianggap tidak memberi keadilan terhadap wajib pajak patuh. Hal yang perlu dikaji bagaimana kebijkan tax amnesty dikaitkan dengan asas keadilan? dan bagaimana model pengampunan pajak yang berkeadilan serta mampu meningkatkan iklim investasi di Indonesia ?Penelitian ini menggunakan metode pendekatan socio legal reseach. Kebijakan tax amnesty harus dipandang dari asas manfaat, yaitu peningkatan penerimaan negara. Upaya memberi keadilan, wajib pajak yang telah diampuni, harus membayar uang tebusan, serta harus ada komitmen penegakan hukum yang tegas. Peningkatan iklim investasi di Indonesia perlu didukung adanya kemudahan birokrasi perijinan, iklim politik yang kondusif, terjaminnya kerahasiaan dan kepastian hukum.
\end{abstract}

Kata Kunci : Pengampunan Pajak, Pajak

A. Pendahuluan

1. Latar Belakang

Negara dalam mewujudkan tujuannya sebagaimana yang tercantum dalam Pembukaan Undang-undang Dasar Negara Republik Indonesia tahun 1945, memberi konsekuensi akan kebutuhan dana yang tidak sedikit. Salah satu sektor yang dijadikan andalan pemerintah sebagai sumber pembiyaan negara adalah sektor pajak. Sebagai sumber penerimaan negara (budgeter), pajak juga dianggap sebagai sektor yang aman, murah dan berkelanjutan (Haula Rosdiana,2012). Pajak dianggap sebagai sektor yang aman dikarenakan bahwa pajak dianggap sebagai bentuk kemandirian negara yang mempunyai derajat yang tinggi yang terhindar dari intervensi negara lain maupun lembaga pinjaman (Haula Rosdiana,2012). "Murah" karena negara tidak terbebani kewajiban pembayaran bunga. "Berkelanjutan" karena pajak mempresentasikan sumber-sumber penerimaan pajak disetiap aktivitas masyarakat, sepanjang pemerintah menjamin keamanan dan mendorong aktifitas masyarakat maka akan selalu ada sumber penerimaan negara (Haula Rosdiana,2012).

\footnotetext{
* Hasil Penelitian, Membangun Model Pengampuan Pajak ( Tax Amnesty) Berdasarkan Asas Keadilan Yang Menduku Iklim Investasi di Indonesia, 2016, Riset Pengembangan dan Penerapan, PNBP DIPA UNDIP
} 
Pajak yang begitu penting sebagai sumber pembiayaan negara, dalam pemungutannya tidak lepas dari beberapa hambatan. Salah satu hambatan serius dalam pemungutan pajak adalah adanya perlawanan dari wajib pajak. Mardiasmo mengelompokkan perlawanan tersebut dalam bentuk "Perlawanan Pasif" dan Perlawanan Aktif" (Mardiasmo,2011). Termasuk dalam perlawanan pasif adalah keengganan masyarakat untuk membayar pajak yang disebabkan karena ketidak fahaman masyarakat akan sistem perpajakan yang ada. Perlawanan aktif menurut Mardiasmo meliputi semua usaha dan perbuatan yang secara langsung ditujukan kepada untuk menghidari kewajiban perpajakan (Mardiasmo,2011). Bentuk perlawanan aktif ini dapat berupa usaha meringankan beban pajak dengan tidak melanggar undangundang (tax avoidence) serta usaha meringankan beban pajak dengan cara melanggar undang-undang atau penggelapan pajak (tax evasion) (Mardiasmo,2011).

Bentuk-bentuk perlawanan pajak tersebut tentunya mengakibatkan adanya kerugian negara atau berkurangnya penerimaan negara dari sektor pajak (tax loss). Berkaitan dengan hal ini Zainal Muttaqin merinci penyebab kerugian negara dari sektor pajak disebabkan antara lain; Pertama, wajib pajak tidak membayar pajak dengan benar atau dengan kata lain tidak melaporkan semua penghasilan yang diterimanya dengan benar. Kedua, wajib pajak melakukan kegiatan ekonomi secara sembunyi-sembunyi dengan maksud menghindari kewajiban perpajakan (underground economy). Ketiga, banyaknya wajib pajak menanamkan modalnya di luar negeri (capital flight), dengan pertimbangan lebih menguntungkan dibanding di dalam negeri (Zainal Muttaqin, 2013).

Tingkat kepatuhan wajib pajak Indonesia dalam kenyataannya dikatakan masih tergolong rendah, hal demikian terlihat dari rendahnya tax ratio Indonesia, serta masih rendahnya jumlah wajib pajak yang melaporkan Surat Pemberitahuan Tahunan (SPT) (Laporan Tahunan Direktorat Jenderal Pajak). Kenyataan juga menunjukkan bahwa banyak warga negara Indonesia yang menyimpan dan menanamkan modalnya di luar negeri. Harta warga negara Indonesia yang tersimpan di luar negeri berdasarkan kajian Bank Indonesia nilainya mencapai Rp.3.147 triliun (Koran Sindo, edisi 26-4 2016).

Banyaknya uang warga negara Indonesia yang tersimpan di luar negeri tentunya menimbulkan potensi kerugian penerimaan negara baik dari sektor pajak serta kurang terdukungnya iklim investasi di Indonesia. Sementara dukungan para investor untuk melakukan investasi merupakan harapan besar bagi semua negara termasuk Indonesia. Hal demikian secara tidak langsung diharapkan dapat meningkatkan pertumbuhan ekonomi dalam suatu negara.

Berdasarkan beberapa kenyataan di atas maka melalui instrumen perpajakan pemerintah berupaya meningkatkan penerimaan dari sektor pajak serta menarik kembali minat orang Indonesia untuk mengalihkan dananya yang selama ini tersimpan di negara asing untuk masuk ke dalam negeri melalui instrumen perpajakan. Pemerintah berusaha mengoptimalkan pajak dalam fungsinya yang lain yaitu fungsi regulerend. Pajak dalam fungsi regulerend di arahkan sebagai alat untuk mengatur dan melaksanakan kebijakan pemerintah baik dalam melaksanakan kebijakan sosial dan ekonomi (Mardiasmo,2011).

Kebijakan pemberian pengampunan pajak (tax amnesty) dianggap pemerintah sebagai upaya yang paling tepat untuk meningkatkan penerimaan negara dari sektor pajak serta mampu menarik kembali dana warga negara Indonesia yang tersimpan di luar negeri. Kebijakan penghapusan pajak (tax amnesty) sendiri sudah pernah dua kali diberikan yaitu pada tahun 1964 yang didasarkan Penetapan Presiden No.5 tahun 1964 dan tahun 1984 yang didasarkan pada Keputusan Presiden No.26 tahun 1984 (Zainal Muttaqin, 2013).

Kebijakan tax amnesty yang diberikan pada tahun 1964 dan tahun 1984 dalam kenyataannya tidak mampu memberi peningkatan penerimaan negara secara signifikan dan dianggap gagal. Kebijakan tax amnesty meskipun telah dua kali mengalami kegagalan pemerintah tetap mengambil 
kembali kebijakan tax amnesty ini sebagai upaya untuk mengoptimalkan penerimaan negara dengan mengeluarkan Undangundang No. 11 tahun 2016 tentang Pengampunan Pajak.

Program pengampunan pajak ini banyak menimbulkan kontroversi di kalangan masyarakat. Pihak yang tidak setuju diberikannya kembali program pengampunan pajak (tax amnesty) ini pesimis bahwa program ini akan mampu menarik investor ke Indonesia serta memberikan sumbangan penerimaan yang signifikan bagi negara. Kebijakan ini dikhawatirkan hanya dimanfaatkan lagi wajib pajak nakal. Koordinator monitoring Indonesian Coruption Watch (ICW) Firdaus Ilyas mengkhawatirkan bahwa para pengemplang pajak setelah mendapat pengampunan pajak akan melenggang kembali ke luar negeri setelah mendapat keuntungan dari program ini (www.hukumonline.com, 7 Maret 2016). Pesimistis akan keberhasilan tax amnesty juga diunggkapkan oleh Yenny Sucipto sekretaris Jenderal Forum Indonesia. Yenny mengatakan bahwa undang-undang pengampunan pajak justru akan menegasikan pengabaian tindakan hukum bagi para investor yang melarikan asetnya keluar negeri dan masuk lagi ke Indonesia tanpa adanya sanksi sedikitpun (www.hukumonline.com, 7 Maret 2016). Hal demikian dianggap justru akan menimbulkan ketidakadilan terhadap wajib pajak patuh.

Kebijakan tax amnesty memang dianggap menimbulkan ketidak adilan terhadap wajib pajak patuh, mengingat bahwa fasilitas perpajakan tax amnesty justru diperuntukkan untuk wajib pajak yang tidak patuh.

Berkaitan dengan beberapa persoalan di atas, membangun kebijakan pengampunan pajak yang mampu memberikan suatu keadilan dan meningkatkan iklim investasi menjadi penting untuk itu perlu dilakukan suatu penelitian sesuai dengan judul di atas.

Berdasarkan beberapa uraian di atas maka dapat dirumuskan beberapa permasalahan sebagai berikut:

1. Bagaimana kebijakan pengampunan pajak (tax amnesty) yang ada apabila dikaitkan dengan asas keadilan perpajakan di Indonesia?

2. Bagaimana model pengampunan pajak (tax amnesty) yang mendasarkan pada asas keadilan serta mampu meningkatkan iklim investasi di Indonesia?

Tulisan ini berbeda dengan tulisantulisan lain, tulisan yang dapat diperbandingkan adalah tulisan Zainal Muttaqin yang berjudul Tax Amnesty di Indonesia. Tulisan Zainal Muttaqin melihat perlunya kebijakan tax amnesty diberi kepastian hukum antara lain melalui landasan pengaturan berupa undang-undang. Berbeda dengan tulisan tersebut, tulisan ini mengkritisi kebijakan tax amnesty pasca keluarnya UU N0.11 tahun 2016 tentang Pengampunan Pajak, serta ingin membangun konsep pengampunan pajak yang mendasarkan pada asas keadilan dan yang mampu meningkatkan iklim investasi di Indonesia.

\section{Metode Penelitian}

Penelitian ini dikelompokkan ke dalam ranah socio legal research, yaitu kajian terhadap hukum dengan menggunakan pendekatan ilmu hukum maupun ilmu-ilmu sosial (Adrian W.Bedner, 2012 ). Pendekatan yang digunakan dalam penelitian ini adalah pendekatan non doktrinal (socio legal approach). Soetandyo Wignjosoebroto mengatakan bahwa penelitian non doktrinal menempatkan hasil amatan atas realitasrealitas sosial untuk ditempatkan sebagai proposisi umum atau premis mayor, sehingga penelitian non doktrinal bukan cuma penguasaan metode berpikir deduktif tetapi justru mengutamakan yang induktif (Soetandyo Wignjosoebroto, 2009). Pengumpulan data primer dilakukan dengan wawancara mendalam ( $i n d e p t h$ interview).Pengumpulan data sekunder yang berupa bahan hukum primer, sekunder dan tersier dilakukan dengan cara menggunakan studi kepustakaan ( library research).Seluruh data yang didapat dianalisis dengan menggunakan metode kualitatif dan disajikan dalam bentuk deskriptif. 


\section{Kerangka Teori}

a. Teori Keadilan John Rawls

Berkaitan dengan permasalahan di atas maka dalam menganalisis serta membangun model pengampunan pajak yang berdasarkan asas keadilan maka dipakai teori Keadilan sebagaimana yang diusung oleh John Rawls. Konsep keadilan menurut John Rawls tertuang dalam bukunya yang berjudul $A$ Theory Of Justice. John Rawls memandang suatu keadilan adalah fairness. Salah satu bentuk keadilan fairness adalah memandang berbagai pihak dalam situasi awal sebagai rasional dan sama-sama netral (John Rawls, 2011). Ada dua prinsip keadilan yang diusung oleh Rawls yaitu (John Rawls, 2011): Pertama, setiap orang mempunyai mempunyai hak yang sama atas kebebasan dasar yang paling luas, seluas kebebasan yang sama bagi semua orang. Kedua, Ketimpangan sosial ekonomi mesti diatur sedemikian rupa sehingga a) Dapat diharapkan memberi keuntungan dan b) Semua posisi dan jabatan terbuka bagi semua orang.

b. Tiga Nilai Dasar Hukum menurut Gustav Radbruch

Ada tiga nilai dasar hukum menurut Gustav Radbruch, yaitu nilai kemanfaatan, keadilan dan kepastian hukum hal demikian sebagaimana dikutip oleh Brian $\mathrm{H}$ Bix yang menyatakan, "Radbruch argued that there were three elements in "the idea of law": justice, "expediency or suitability for a purpose," and legal certainty. (Brian H Bix, 2011) Lebih lanjut dalam tulisan Brian H Bix yang mengutip pendapatnya Gutav Radburch, menyebutkan bahwa ketiga nilai tersebut yaitu keadilan, kemanfaatan dan kepastian hukum dalam praktik seringkali menimbulkan benturan untuk didahulukan dan keitga nilai tersebut mempunyai nilai yang sama.

Ketika dalam realitasnya, terjadi benturan antara nilai keadilan, kemanfaatan dan kepastian hukum maka harus diterapkan asas prioritas dari ketiga nilai dasar yang menjadi tujuan hukum tersebut (Antonius Sudirman, 2007). Brian H Bix juga mengutip pendapatnya Gustav Radbruch, yang menyatakan, "Apabila ada ketegangan diantara ketiga nilai tersebut keputusannya adalah kembali pada hati nurani. Hal tersebut seperti apa yang ditulis, Brian H Bix sebagai berikut:" Radbruch spoke of the tension between "the demands of legal certainty," on one hand, and "the demands of justice and expediency," on the other." While he adds that "the three aspects of the idea of law are of equal value, and in case of conflict there is no decision between them but by the individual conscience," (Brian H Bix, 2011).

c. Teori The Four Cannon Maxims Of Adam Smith.

Pemungutan pajak oleh negara harus dilandasi dengan asas-asas yang merupakan ukuran untuk menentukan adil tidaknya pemungutan pajak (Bohari,2002) . Pajak sebagai instrumen keadilan dapat dilihat dari dua hal, yaitu: (Tjia Siauw Jan, 2013)

a. Dari sisi kebijakan pajak, misalkan dengan menerapkan asas keadilan vertikal dan horizontal dalam menentukan beban pajak yang harus ditanggung wajib pajak.

b. Dari sisi belanja / pengeluaran pemerintah.

Adam Smith dalam bukunya "Wealth Of Nations " mengemukakan empat asas pemungutan pajak yang lazim disebut "The Four Canons Maxims Taxation", atau sering disebut juga "The Four Canons Of Adam Smith “. Lebih lanjut dinyatakan, bahwa supaya peraturan pajak adil harus memenuhi syarat: (Rochmat Soemitro, Dewi Kania, 2010)

Asas kesamaan ( equality) dan keadilan (equity). Asas equality mengandung arti orang yang berada dalam keadaan yang sama harus dikenakan pajak yang sama. Asas equity dalam bahasa Indonesia sering diterjemahkan dengan keadilan, tetapi penerjemahan ini menurut Rochmat Soemitro dianggap kurang tepat, yang lebih tepat adalah kepatutan atau keadilan dalam arti khusus, karena menurut bahasa Jerman ada pembedaan pengertian gerechtigkeit dan billigkeit, dalam bahasa Belanda juga ada pembedaan istilah rechtvaardigheid dan billijkheid, sedangkan dalam bahasa Inggris ada lawful dan equity. Berdasarkan pembedaan tersebut, equity lebih tepat diartikan sebagai kepatutan. Lebih lanjut dikatakan keadilan tidak bisa disamakan 
dengan kepatutan. Kadangkala ketentuan hukum secara umum dapat dikatakan adil, karena adanya perlakuan yang sama (equality), tetapi ada kalanya bahwa apa yang adil secara umum, belum tentu adil dalam kasus tertentu (Rochmat Soemitro, Dewi Kania,2010).

Asas kepastian hukum ( certainty). Asas ini merupakan tujuan dari setiap undang-undang. Pembuatan suatu undangundang atau peraturan-peraturan yang mengikat umum harus diusahakan supaya ketentuan yang dimuat dalam undang-undang adalah jelas, tegas dan tidak mengandung arti ganda atau memberi peluang untuk ditafsirkan lain.

Asas tepat waktu (convenience of payment). Pajak harus dipungut pada saat yang tepat, yaitu pada saat wajib pajak mempunyai uang, ini akan mengenakkan wajib pajak ( convenient), hal demikian juga dimaksudkan agar pembayaran pajak tidak terlalu memberatkan wajib pajak.

Asas economic of collection, syarat ini bertalian dengan biaya pemungutan pajak. Pembuatan peraturan perundang-undangan pajak baru harus memperhatikan biaya pengeluaran, biaya pemungutan pajak harus relatif kecil dibanding dengan uang pajak yang masuk.

\section{B. Hasil dan Pembahasan}

1. Kebijakan Pengampunan Pajak (Tax Amnesty) Dikaitkan dengan Asas Keadilan Perpajakan di Indonesia

Dewan Perwakilan Rakyat Republik Indonesia pada akhirnya mengesahkan rancangan undang-undang pengampunan pajak (tax amnesty) menjadi Undang-undang No. 11 tahun 2016 tentang Undang-undang Pengampunan Pajak ( Selanjutnya disebut UU No. 11 tahun 2016). Konsideran UU No.11 tahun 2016 menyebutkan bahwa kebijakan pengampunan pajak diambil dalam rangka meningkatkan penerimaan negara dan pertumbuhan perekonomian serta kesadaran dan kepatuhan masyarakat dalam pelaksanaan kewajiban perpajakan. Lebih lanjut konsideran UU No.11 tahun 2016 secara implisit menyatakan bahwa kebijakan pengampunan perpajakan diambil karena masih banyak wajib pajak yang selama ini belum patuh dan jujur dalam melaporkan harta yang dimiliki baik yang berada di dalam negeri maupun yang berada di luar negeri.

Perlu diakui pajak pada umumnya masih dirasakan sebagai suatu pembebanan sehingga tidak dapat dipungkiri masyarakat mempunyai kecenderungan enggan membayar pajak. Kesadaran masyarakat Indonesia untuk melakukan pembayaran pajak juga terlihat dari tax ratio (rasio pajak ) Indonesia. Tahun 2012: 11,78\%, tahun 2013: $11,91 \%$ dan $2014: 11,86 \%$, tahun 2015: 10,55 \% (Laporan Tahunan DJP). Rendahnya tax ratio Indonesia diakui oleh Sigit Priadi Pramudito, tax ratio lebih rendah dibanding Singapura $14 \%$, Filipina 12,9\%, Thailand $16.5 \%$ dan Malaysia: 16,1\% (Infobanknews.com, 11 Agustus 2015).

Kebijakan pengampunan pajak tidak dapat dipungkiri menimbulkan kontroversi dari berbagai kalangan. Pihak yang kontra atas kebijakan tersebut menilai bahwa kebijakan pengampunan pajak dianggap sebagai kebijakan yang tidak memberi keadilan terhadap wajib pajak patuh (Wawancara Ecky Muharam, Anggota DPR RI dari Fraksi PKS). Lebih lanjut Ecky Muharam mengatakan bahwa, " Perbuatan tidak melaporkan hasil kekayaan merupakan suatu pelanggaran, merupakan kesalahan besar memberi pengampunan terhadap orang yang merugikan keuangan negara (Wawancara Ecky Muharam, Anggota DPR RI dari Fraksi PKS).

Berlatar belakang kondisi ketidak mampuan negara dalam mengatasi ketidak patuhan wajib pajak inilah, sebagai upaya untuk memperbaiki sistem perpajakan dan pengoptimalan penerimaan pajak bagi negara maka kebijakan pengampunan pajak dianggap sebagai solusi atas kebuntuan tersebut. Berkaitan dengan hal ini Zainal Muttaqin menyatakan, pada dasarnya pemberian pengampunan pajak merupakan suatu pilihan kebijakan dalam menghadapi ketidakmampuan negara membiayai penyelenggaraan pemerintah .

Berdasarkan aspek yuridis khususnya dari aspek keadilan, kebijakan pengampunan pajak dapat dimengerti sebagai bentuk perlakuan yang tidak adil dari pemerintah karena ada perlakuan khusus terhadap wajib 
pajak yang tidak patuh membayar pajak, justru diampuni untuk tidak membayar utang pajaknya, sanksi adminstrasinya, sanksi pidana pajaknya dan sebagainya setelah membayar uang tebusan.

Adanya fasilitas tersebut tentunya dapat difahami apabila dirasa "melukai" rasa keadilan masyarakat khususnya wajib pajak yang selama ini patuh membayar pajak. Keberadaan wajib pajak tidak patuh bahkan dapat memberi dampak negatif bagi wajib pajak tidak patuh. Hal demikian bahkan dapat dikategorikan sebagai salah satu biaya atau beban dalam perpajakan ( Haula Rosdiana,2012). The five component costs of taxation are compliaence costs, administrative costs, deadweight effiency lost from taxation, burden of tax the excess burden of tax evasion, and avoidance costs (Jeff Pope, 1993).

Meskipun kebijakan tax amnesty dianggap mencederai keadilan terhadap wajib pajak patuh, tetapi kebijakan tersebut harus dipandang dari asas manfaat, bahwa tujuan tax amnesty dalam jangka panjang adalah peningkatan penerimaan negara dari sektor pajak melalui perluasan wajib pajak dan penatan basis administrasi pajak.

Tiga nilai hukum keadilan, kepastian hukum serta kemanfaatan secara ideal memang harus berjalan secara bersamaan, tetapi ternyata dalam praktik kadangkala satu nilai mendominasi sehingga menggeser nilai yang lain. Berkaiatan dengan hal tersebut kebijakan tax amnesty harus dilihat dari sisi manfaat khususnya dalam jangka panjang. Tax amnesty dalam jangka pendek bertujuan untuk mendapat penerimaan pajak melalui uang tebusan dan untuk jangka panjang meningkatkan penerimaan pajak berdasarkan basis data yang lengkap dan akurat. Mengomentari bahwa pengampunan pajak menimbulkan ketidakadilan bagi wajib pajak patuh, mendasarkan pada penjelasan undangundang secara ekplisit menyatakan bahwa kebijakan ini justru merupakan kebijakan yang diambil dengan mendasarkan pada asas keadilan. Fakta yang menunjukan masih banyaknya aktifitas ekonomi yang belum atau tidak dilaporkan justru dianggap mengusik rasa keadilan dari wajib pajak patuh yang telah berkontribusi besar terhadap penerimaan negara.

Mendasarkan prinsip keadilan yang diusung oleh Rawls sebagaimana yang diuraikan di atas dimana setiap orang mempunyai mempunyai hak yang sama atas kebebasan dasar yang paling luas, seluas kebebasan yang sama bagi semua orang. maka keadilan dalam pemungutan pajak terpenuhi ketika orang dalam kondisi yang sama harus diberi perlakuan yang sama. Hal ini dapat diartikan ketika seseorang telah memenuhi kriteria sebagai wajib pajak, maka orang tersebut harus dibebani kewajiban pembayaran pajak yang sama pula. Wajib pajak yang selama ini tidak patuh harus dipaksa untuk memenuhi kewajibannya meskipun harus dengan cara memberi pengampunan untuk menundudukkannya menjadi wajib pajak patuh. Hal demikian juga untuk mengatasi ketimpangan antara wajib pajak patuh dan tidak patuh. Sistem pemungutan pajak kita juga mendasarkan pada asas equality dan equity, bahwa dalam kedudukan yang sama wajib pajak harus diperlakukan sama menjadi dasar pertimbangan kebijakan pengampunan ini.

\section{Pengampunan Pajak (Tax Amnesty) yang Mendasarkan pada Asas K e a d i l a n S e r t a M a m p u Meningkatkan Iklim Investasi di Indonesia}

Kebijakan pengampunan perpajakan disatu sisi dirasa menimbulkan ketidak adilan bagi wajib pajak lain, tetapi kebijakan ini sudah di sahkan dalam suatu undang-undang, yang mengandung arti bahwa rakyat melalui wakilnya yang ada di DPR telah menyetujui kebijakan tersebut.

Beberapa pertimbangan disetujuinya kebijakan pengampunan ini adalah, dalam masa yang akan datang diharapkan mampu memberi kemanfaatan yang besar terhadap peningkatan pertumbuhan ekonomi nasional. Harapan yang ingin dicapai dalam pengambilan kebijakan tax amnesty bahwa kebijakan ini diharapkan dapat mempengaruhi penerimaan negara yang besar, APBN sustainable, yang secara tidak langsung akan berdampak pada pelaksanaan pembangunan infrastruktur yang lebih baik dan pengurangi angka pengangguan yang 
akan sampai pada upaya mensejahterakan rakyat.

Hal demikian sesuai dengan pendapat yang dikemukan Gustav Radbruch bahwa idealnya elemen hukum mampu berjalan bersamaan tetapi terkadang dalam praktikmenunjukkan ketika salah satu elemen harus diprioritaskan, maka akan menggeser elemen yang lain. Kebijakan pengampunan pajak disatu sisi dapat dirasa menimbulkan ketidakadilan bagi wajib pajak patuh, tetapi disatu sisi harus dilihat dari tujuan atau manfaat, pengambilan kebijakan pengampunan harus dipandang sebagai upaya yang dilakukan oleh pemerintah untuk menggali potensi penerimaan dari sektor pajak melalui perluasan basis data wajib pajak. Pelaksanaan pengampunan pajak agar mampu memberi keadilan dan kepastian hukum bagi masyarakat sudah barang tentu di butuhkan komitmen yang tinggi dari fiskus untuk mengawal program ini. Komitmen yang tinggi dari fiskus merupakan salah satu kunci suksesnya kebijakan tax amnesty.

Mengenai kesuksesan tax amnesty ini, Gubernur Bank Indonesia Agus Martowardojo mengatakan,lima kunci kebijakan untuk menyukseskan tujuan tax amnesty: (www.pasbana.com)

Pertama, tax amnesty harus dirancang sebagai titik tolak dari sistem perpajakan yang baru melalui rekonsiliasi data atau tax reform.

Kedua, Direktorat Jenderal Pajak harus memiliki data akurat dan membangun administrasi perpajakan yang kuat dan efektif. Wajib pajak yang mendapat amnesti harus dipantau secara ketat. Bahkan harus dipersiapkan peningkatan audit dan pengenaan sanksi yang lebih berat bagi wajib pajak yang mengabaikan kesempatan untuk diamnesti.

Ketiga, kebijakan ini harus bersifat mengikat bagi semua pengaju pengampunan pajak dengan pelaksanaan yang jelas.

Keempat, pengampunan pajak seharusnya dilakukan secara mendadak dengan durasi yang sangat singkat, yakni maksimal setahun.

Kelima, kebijakan ini harus diikuti dengan penindakan hukum yang tegas untuk menjamin efektivitas pengampunan yang akan diberikan.

Selain itu, hal penting lainnya juga pemerintah perlu untuk menghitung seberapa besar rasio biaya dan manfaat agar kebijakan ini semakin komprehensif. Salah satu hal penting untuk diperhatikan adalah bagaimana mengelola sisi psikologis dari wajib pajak yang selama ini sudah cukup patuh terhadap aturan perpajakan sehingga Tax Amnestry ini menjadi efektif dan diterima secara adil bagi semua Wajib Pajak.

Setelah masa pengampunan habis, komitmen yang harus di kerjakan pemerintah:

1. Pengadministrasian data base dengan benar

2. Penegakan hukum law enforcemen yang tegas

3. Melakukan kerjasama pertukaran data antar bank Automatic Exchange System

4. Mengawasi penggunakan hasil pajak.

Hal inilah yang perlu dilakukan untuk mampu mencapai peningkatan investasi di Indonesia.

\section{Simpulan :}

1. Kebijakan tax amnesty meskipun disatu sisi dianggap mencederai keadilan terhadap wajib pajak patuh, tetapi kebijakan tersebut harus dipandang dari asas manfaat, bahwa tujuan tax amnesty dalam jangka panjang adalah peningkatan penerimaan negara dari sektor pajak melalui perluasan wajib pajak dan penatan basis administrasi pajak.

2. Pelaksanaan pengampunan pajak agar mampu memberi keadilan dan kepastian hukum bagi masyarakat sudah barang tentu di butuhkan komitmen yang tinggi dari fiskus untuk mengawal program ini, m e 1 a 1 u i e la k s a a $n$ pengadministrasian yang baik serta law enforcement yang tegas atas setiap pelanggaran perpajakan. Terkait dengan tujuannya meningkatkan iklim investasi, bahwa pembebasan atau fasilitas pajak bukanlah satu-satu nya instumen yang mampu menarik minat investor untuk berinvestasi di Indonesia, 
tetapi juga harus didukung oleh faktor antara lain; kemudahan birokrasi perijinan, iklim politik yang kondusif, terjaminnya kerahasiaan, jaminan kepastian hukum.

\section{DAFTAR PUSTAKA}

\section{Buku :}

Adrian W.Bedner ( et.al), 2012, Kajian Sosio Legal ( Seri Unsur-unsur Penyusunan Bangunan Negara Hukum, Denpasar Bali, Pusndyotaka Larasan

Antonius Sudirman, 2007, Hati Nurani Hakim dan Putusannya: Suatu Pendekatan dari Perspektif Ilmu Hukum (Behavioral Jurisprudence), Kasus Hakim Bismar Siregar, Bandung, Citra Aditya Bakti

Bohari,2002, Pengantar Hukum Pajak,Jakarta, PT.Raja Grafindo Persada.

Haula Rosdiana,2012, Pengantar Ilmu Pajak (Kebijakan dan Implementasi di Indonesia), Jakarta, Rajagrafindo Persada

John Rawls, 2011, A Theory of Justice, Terjemahan Uzair Fauzan dan Heru Prasetyo, Yogyakarta, Pustaka Pelajar

Mardiasmo,2011, Perpajakan (Edisi Revisi), Yogyakarta,Andi Yogyakarta

Rochmat Soemitro, Dewi Kania,2010, Asas Dan Dasar Perpajakan 1Edisi Revisi, Bandung, Refika Aditama

Soetandyo Wignjosoebroto, 2009, Ragamragam Penelitian Hukum dalam Sulistyowati Irianto dan Sidharta ( Editor ), Metode Penelitian Hukum, Konstelas $i$ dan Refleksi, Jakarta, Yayasan Obor Indonesia,

Tjia Siauw Jan, 2013,,Pengadilan Pajak, Upaya Kepastian Hukum dan Keadilan Bagi Wajib Pajak, Bandung, Alumni Bandung

Zainal Muttaqin, 2013,Tax Amnesty di Indonesia, Bandung, Refika Aditama

\section{Jurnal :}

Brian H Bix, 2011,Radbruch's Formula and Conceptual Analysis, The American Journal Of Jurisprudence, University Minnesota, vol 56,
Jeff Pope, 1993,The Compliance Costs of Taxation in Australia and Tax Simplication, The Issues, Australian Journal of Management, The University Of New South Wales, June, 1993

\section{Internet dan Media Massa :}

http://www.pasbana.com/2016/08/prokontra-tax-amnesty-di-indonesia.html, diakses tgl. 10 Agustus 2016.

Infobanknews.com, 11 Agustus 2015

Koran Sindo, edisi 26-4 201

Laporan Tahunan Direktorat Jenderal Pajak www.hukumonline.com, 7 Maret 2016 